\title{
Hygienic-sanitary quality of Minas fresh cheese sold in the city of Botucatu, São Paulo
}

\author{
Avaliação higiênico-sanitária de queijos Minas frescal \\ comercializados na cidade de Botucatu, São Paulo
}

\author{
Murilo Mariz Queiroz' ${ }^{*}$, Bruna Fernanda Rossi' ${ }^{1}$ Ivana Giovannetti Castilho', Vera Lucia Mores Rall ${ }^{1}$

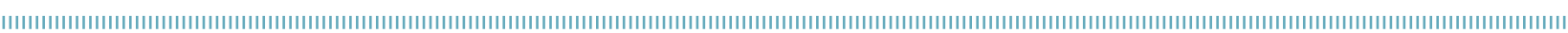

\begin{abstract}
The Minas fresh cheese is a fresh and moist cheese and, therefore, has a short shelf-life. The use of raw milk as the main feedstock, the absence of ripening and the facility of contamination are factors that can compromise the product's microbiological quality. The aim of this study was to describe the hygienic-sanitary quality of 50 Minas fresh cheeses marketed in Botucatu city, Sáo Paulo, Brazil, close to their production date, and another 50 units from the same lot exactly on the expiration date, according to the Brazilian Sanitary Surveillance Agency (ANVISA). We also searched for enterotoxins genes in Staphylococcus aureus and its in vitro expression. In $36 \%$ of the first analyzed samples, the count of coliforms at $45^{\circ} \mathrm{C}$ was above the limit and, as for the second analysis, $44 \%$. Regarding coagulase positive staphylococci, 10 (20\%) samples showed concentration above the permitted by law next to the production date and $14 \%$ on the expiration date. Salmonella was only observed in one sample analyzed near the date of production, while L. monocytogenes only in one sample analyzed on the expiration day. We isolated three enterotoxigenic strains of $S$. aureus that produced Staphylococcal Enterotoxin $B$ (SEB) and Staphylococcal Enterotoxin C (SEC) in vitro, highlighting the importance of proper storage of this product due to its potential to cause intoxication. Overall, the quality of Minas fresh cheese is still unsatisfactory, leading to risks to consumers' health.
\end{abstract}

KEYWORDS: food safety; sanitary condition; foodborne diseases; dairy products.
RESUMO: O queijo Minas frescal é muito apreciado no Brasil. Por ser fresco e úmido, seu tempo de prateleira é curto. A utilização de leite cru como matéria prima, a não maturaçáo do queijo e a facilidade de contaminação durante seu processamento são fatores que comprometem a qualidade microbiológica do produto. Este trabalho verificou a qualidade higiênico-sanitária de 50 queijos Minas frescal comercializados na cidade de Botucatu, São Paulo, Brasil, em datas próximas a sua fabricação e na data de expiraçáo da validade, utilizando os parâmetros propostos pela RDC no 12 da Agência Nacional de Vigilância Sanitária (ANVISA). Cepas de $S$. aureus foram submetidas à pesquisa de genes codificadores de produção de enterotoxinas clássicas e, também, sua produçấo in vitro. Encontraram-se coliformes a $45^{\circ} \mathrm{C}$, acima do permitido por legislação, em 36\% das amostras durante a primeira análise e, na segunda, em 44\%. Quanto à contagem de estafilococos coagulase positiva, $10 \%$ não atendiam ao padrão exigido por lei na data de produção, e 14\%, na data de expiraçáo da validade. Salmonella foi apenas observada em uma amostra próxima à data de produção, enquanto L. monocytogenes somente em uma amostra na data de expiração da validade. Observou-se produção de Staphylococcal Enterotoxin $B$ (SEB)e Staphylococcal Enterotoxin $C$ (SEC) in vitro por três cepas de $S$. aureus. Ressalta-se, em decorrência disso, a importância de armazenar corretamente esse alimento, por seu potencial de causar intoxicaçáo. Concluiu-se que a qualidade higiênico-sanitária desses queijos Minas frescais foi insatisfatória, implicando riscos para a saúde do consumidor.

PALAVRAS-CHAVE: segurança de alimentos; condição sanitária; doenças transmitidas por alimentos; produtos lácteos. 
Brazilians widely enjoy Minas fresh cheese. It is a white, tender, and fresh cheese, with a slightly acidic flavor. Because of its high production yield, it is traded at accessible prices, which increases its popularity among large population groups (SENA et al., 2000; SILVA et al., 2003). It ranks as the fourth most produced cheese in the country and is produced mainly in small and medium plants in Southern and Southeastern regions of Brazil (OLIVEIRA et al., 1998; OLIVEIRA; BRITO, 2006). Pasteurized milk should be used in its preparation process, as required by law. However, it is common to find products being traded without meeting this requirement (PEREIRA et al., 1991). Minas fresh cheese is not a ripened cheese. Therefore, it has a short shelf-life, which means it must be traded right after it is produced (FURTADO, 1999). However, especially in larger establishments, these cheeses reach the shelves seven to ten days after the date of production (ROCHA et al., 2006).

Cheeses are often considered carriers of pathogens, especially fresh and artisanal cheeses (FEITOSA et al., 2003). They can be easily contaminated between the milking process and their arrival on the retail market, even when a heat treatment or a pasteurization process are conducted in the initial stages of production. Because they do not need to be cleaned or cooked before being eaten, consumers are susceptible to foodborne diseases. These diseases are caused mainly by Staphylococcus aureus, Salmonella, pathogenic Escherichia coli, and, but not often, Listeria monocytogenes (DE BUYSER et al., 2001; KOUSTA et al., 2010).

Therefore, this paper aimed to describe the profile of hygiene practices and sanitary conditions related to Minas fresh cheese and compare this profile to the prevailing legislation (Resolução de Diretoria Colegiada - RDCNo. 12 of Brazilian Sanitary Surveillance Agency - ANVISA) at two different moments: close to the date of production and at the expiration date. The isolated strains of $S$. aureus were also analyzed to discover if they were enterotoxigenic.

For this purpose, two 50-unit sets of Minas fresh cheeses that were close to their production date were purchased in the city of Botucatu, São Paulo, Brazil. They came from different producers and establishments, 11 of which were artisanal producers. From those 100 samples, 50 were analyzed right after they were purchased, and the other 50 , on their expiration date after they were kept stored in a domestic refrigerator $\left(4^{\circ} \mathrm{C}\right)$ to simulate the consumption conditions of a common household.

To evaluate the hygiene quality and sanitary conditions of those dairy products, microbiological parameters proposed by the RDC No. 12 of ANVISA (BRASIL, 2001) were used. These parameters comprise the coagulase-positive staphylococci (CPS) count, the most probable number of coliforms at $45^{\circ} \mathrm{C}$ $(\mathrm{TtC})$ and the presence of Salmonella and Listeria monocytogenes in $25 \mathrm{~g}$ of cheese. Oxoid was the brand of all culture media, and, when different brands were used, we specified them.

The LANCETTE; BENNETT (2001) methodology was used to identify the coagulase-positive Staphylococcus. Serial dilutions were plated on Baird-Parker agar and incubated at $35^{\circ} \mathrm{C}$ for 48 hours. Characteristic colonies were tested for catalase production, and, if the results were positive, a coagulase test was performed. Next, a Staphytect Test Dry Spot (Oxoid, Basingstoke, United Kingdom) kit was used to isolate the $S$. aureus, and when agglutination was observed, a Voges-Proskauer test was performed, to which it was positive.

Polymerase Chain Reaction (PCR) was used to search for the nuc gene (to confirm S. aureus), and for sea, seb, sec and sed genes which encode staphylococcal enterotoxins Staphylococcal Enterotoxin A (SEA), Staphylococcal Enterotoxin B (SEB), Staphylococcal Enterotoxin C(SEC) and Staphylococcal Enterotoxin D (SED), respectively (JOHNSON et al., 1991; CRLAR, 2009; with modifications). The Mini Spin kit (GE Healthcare, Little Chalfont, United Kingdom) was used to isolate and purify DNA according to the instructions of the manufacturer. A total volume of $15 \mu \mathrm{L}$ for each sample was used in the PCR reactions, which comprised 7.5 $\mu \mathrm{L}$ of GoTaq Green Master Mix (Promega, Madison, Wisconsin, United States), $5.5 \mu \mathrm{L}$ of Nuclease-Free Water (Promega, Madison, Wisconsin, United States), $0.5 \mu \mathrm{L}$ of each primer (Table 1) with a concentration of $10 \mathrm{pmol}$ and $1 \mu \mathrm{L}$ of the DNA template.

Table 1. Characteristics of the primers used in this study for Staphylococcus aureus comprovation and detection of enterotoxins A, $B, C$ and $D$ genes.

\begin{tabular}{|c|c|c|c|c|c|}
\hline Gene & Primer & Sequence $\left(5^{\prime} \rightarrow 3^{\prime}\right)$ & Product Length (bp) & $\begin{array}{l}\text { Annealing } \\
\text { Temperature }\end{array}$ & Reference \\
\hline \multirow{2}{*}{ nuc } & NUC-1 & Tcagcaaatgcatcacaaacag & \multirow{2}{*}{287} & \multirow{2}{*}{$55^{\circ} \mathrm{C}$} & \multirow{2}{*}{ CRLAR (2009) } \\
\hline & NUC-2 & Cgtaaatgcacttgcttcagg & & & \\
\hline \multirow{2}{*}{ sea } & SEA-1 & Ttggaaacggttaaaacgaa & \multirow{2}{*}{120} & \multirow{2}{*}{$50^{\circ} \mathrm{C}$} & \multirow{2}{*}{ Johnson et al. (1991) } \\
\hline & SEA-2 & gaaccttcccatcaaaaaca & & & \\
\hline \multirow{2}{*}{ seb } & SEB-1 & Tcgcatcaaactgacaaacg & \multirow{2}{*}{478} & \multirow{2}{*}{$50^{\circ} \mathrm{C}$} & \multirow{2}{*}{ Johnson et al. (1991) } \\
\hline & SEB-2 & Gcaggtactctataagtgcc & & & \\
\hline \multirow{2}{*}{$\mathrm{sec}$} & SEC- 1 & Gacataaaagctaggaattt & \multirow{2}{*}{257} & \multirow{2}{*}{$50^{\circ} \mathrm{C}$} & \multirow{2}{*}{ Johnson et al. (1991) } \\
\hline & SEC-2 & Aaatcggattaacattatcc & & & \\
\hline \multirow{2}{*}{ sed } & SED- 1 & Ctagtttggtaatatctcct & \multirow{2}{*}{317} & \multirow{2}{*}{$50^{\circ} \mathrm{C}$} & \multirow{2}{*}{ Johnson et al. (1991) } \\
\hline & SED-2 & Taatgctatatcttataggg & & & \\
\hline
\end{tabular}


The reaction occurred in a Gene Amp PCR System 9700 (Applied Biosystem, Wellesley, United States).

PCR products were submitted to electrophoresis (Electrophoresis Power Supply Model EPD 600 - AmershamPharmacia Biotech Inc., Little Chalfont, United Kingdom) in a $1.5 \%$ agarose gel (Sigma-Aldrich, St. Louis, Missouri, United States) submerged in 0.5XTris-Borate-EDTA (TBE) buffer and stained with SYBR Green (Invitrogen, Carlsbad, California, United States). A comparative analysis was performed between the DNA fragments and 50 bpDNA markers (50 Base Pair Ladder - Amersham - Pharmacia Biotech Inc., Piscataway, New Jersey, United States). They were visualized and photographed by using an image analyzer (Alphaimager Alpha Essay FC Software - Alpha Innotech, San Leandro, California, United States).

The in vitro production of enterotoxins was researched in strains of $S$. aureus that had at least one of these genes. To that end, they were cultivated in Brain Heart Infusion (BHI) broth at $37^{\circ} \mathrm{C}$ for 24 hours. BHI agar plates (supplemented with $1 \%$ yeast extract) covered by a sterile cellophane film received $0.1 \mathrm{~mL}$ aliquots of culture, and, with the help of a Drigalski spatula, a spread plate technique was performed, followed by incubation at $37^{\circ} \mathrm{C}$ for 24 hours. Later, $2.5 \mathrm{~mL}$ of $\mathrm{Na}_{2} \mathrm{HPO}_{4}(0.01 \mathrm{M})$ was added to the cellophane and then homogenized with the microbial growth (DONNELLY et al., 1967).

The resulting volume was transferred into a microcentrifuge tube and centrifuged at 10,000 rpm for 10 minutes at $4^{\circ} \mathrm{C}$ (ROBBINS et al., 1974). The supernatant was submitted to a Reversed Passive Latex Agglutination - RPLA kit (Oxoid, Basingstoke, United Kingdom). This technic allows soluble antigens, such as bacterial toxins, to be detected by agglutination.

Salmonella was detected by following the methodology described by ANDREWS et al. (2001). To that end, $25 \mathrm{~g}$ of cheese was weighed aseptically and homogenized in a Stomacher (Seward, Worthing, West Sussex, United Kingdom) with 225 $\mathrm{mL}$ of buffered peptone water, and then incubated at $35^{\circ} \mathrm{C}$ for 24 hours. After this incubation period, $1 \mathrm{~mL}$ was pipetted into a Tetrathionate broth, and $0.1 \mathrm{~mL}$ was pipetted into a Rappaport-Vassiliadis broth. Then, both were incubated for 24 hours, the first one at $35^{\circ} \mathrm{C}$ and the latter at $42^{\circ} \mathrm{C}$. An aliquot of these broths was plated on XLDand Salmonella-Shigella agars and then incubated at $35^{\circ} \mathrm{C}$ for 24 hours. Characteristic colonies were biochemically tested using Triple Sugar Iron (TSI) and Phenylalanine agars. The strains with typical biochemical profile were submitted to the API 20E (bioMérieux, Rio de Janeiro, Rio de Janeiro, Brazil) and to anti-flagellar and anti-somatic polyvalent serums (Probac do Brasil Produtos Bacteriológicos, São Paulo, São Paulo, Brazil).

The most probable number (MPN) of coliforms at $45^{\circ} \mathrm{C}$ $(\mathrm{TtC})$ was determined by using the multiple-tube technique (KORNACKI; JOHNSON, 2001). In the presumptive test,
$1 \mathrm{~mL}$ of dilutions of the homogenized sample was inoculated in a series of three tubes per dilution, which contained Lauryl Sulphate broth and inverted Durham tubes. The tubes were incubated at $35^{\circ} \mathrm{C}$ for 48 hours. The confirmation of coliforms at $45^{\circ} \mathrm{C}$ was obtained by transferring three swabs from each positive tube (that presented growth and the production of gas) to the Escherichia coli (EC) broth and incubating it in a Biochemical Oxygen Demand (BOD) incubator at $45^{\circ} \mathrm{C}$ for 24 hours. Next, a reading was performed, and the tubes of EC broth showing production of gas in the Durham tube were considered positive. The MNP of coliforms per gram of sample at $45^{\circ} \mathrm{C}$ was determined by using a standard table.

To detect the L. monocytogenes, an aliquot of $25 \mathrm{~g}$ of the sample was aseptically weighed and homogenized in a Stomacher with $225 \mathrm{~mL}$ of Listeria Enrichment broth, and then incubated at $30^{\circ} \mathrm{C}$. After 24 hours, and then after 48 hours, aliquots were plated on PALCAM agar and incubated at $35^{\circ} \mathrm{C}$ for 48 hours. The characteristic colonies were tested for gram coloration, catalase and motility at $25^{\circ} \mathrm{C}$. Next, a CAMP-like test and the ability to ferment D-xylose were performed (RYSER; DONNELLY, 2001).

Minas fresh cheese can be categorized as a high humidity cheese $(46 \%)$ or a very high humidity cheese $(55 \%)$. The RDC No. 12 of ANVISA (BRASIL, 2001) demands that high humidity cheeses have a $\mathrm{TtC}$ count lower than $5 \times 10^{3} \mathrm{MPN} / \mathrm{g}$, CPS count lower than $10^{3} \mathrm{CFU} / \mathrm{g}$ and absence of Salmonella spp. and L. monocytogenes in $25 \mathrm{~g}$ of the product. In very high humidity cheeses, the count of $\mathrm{TtC}$ must be $5 \times 10^{2} \mathrm{MPN} / \mathrm{g}$ or lower, $5 \times 10^{2} \mathrm{CFU} / \mathrm{g}$ or lower of CPS and must have absence of Salmonella spp. and L. monocytogenes in $25 \mathrm{~g}$ of the product. Because the label does not show this categorization, the most demanding parameter was adopted. The results are seen in the sequence (Table 2).

These results showed that some producers have inadequate hygiene and sanitary practices during the different stages of production, transportation and/or storage of the product. This negligence creates risks to the consumer's health, especially of children, the elderly, pregnant women and immunosuppressed individuals.

S. aureus was found in two (4\%) of the samples that were first analyzed, one of which was of artisanal origin. One of these strains had the $s e b$ and $\sec$ genes, and another only had the sec gene. Both strains expressed enterotoxins production in vitro by all the present genes.

S. aureus was isolated in seven (14\%) of the 50 samples that were analyzed in their expiration date. All of them had the sec gene, and three (6\%) also had the seb gene. Among the three strains that had both genes, only one produced both enterotoxins, and the other two produced only SEC. The other four strains did not synthesize the toxin in vitro. Two of the three samples from which enterotoxigenic $S$. aureus was isolated were of artisanal origin. 
The profile of the two strains of $S$. aureus (genes and toxin production) found in the initial samples was also observed in the samples from the same production lot at their expiration date. They were probably the same strains, isolated at these two moments of the study, which demonstrates the survival of the $S$. aureus throughout the entire period of validity of the cheeses, thus highlighting the importance of correctly storing these products.

S. aureus was isolated from nine (9\%) of the 100 analyzed samples, and all strains had at least one of the researched genes, and five (5\%) showed in vitro production of toxins. It is important to point out that the production lots coincided in two of the samples (production/expiration). Therefore, only three samples of cheeses showed enterotoxigenic strains of this bacterium.

These results corroborate with RALL et al. (2008), who isolated 57 strains of $S$. aureus from raw and pasteurized milk, with concentrations of up to $8.9 \times 10^{5}$ and $8.7 \times 10^{3} \mathrm{CFU} / \mathrm{mL}$, respectively. From those samples, 39 (68.4\%) showed at least one studied enterotoxin gene. Among the classic enterotoxins, the sea was the most observed one ( 16 strains, $41 \%$ ), followed by the sec (8 strains, $20.5 \%$ ), sed (5 strains, $12.8 \%$ ), seb (3 strains, $7.7 \%$ ), and see (2 strains, 5.1\%).

The possibility of expression of these genes is exacerbated by the production of biofilms in milk or dairy processing plants. MARTIN et al. (2016) confirmed the ineffectiveness of hygiene protocols in removing enterotoxigenic $S$. aureus adhered to the surface of stainless steel and polypropylene especially at $35^{\circ} \mathrm{C}$. These authors believe that the high occurrence of S. aureus in Minas fresh cheese processing plants can be reduced by following the good manufacturing practices, using good-quality raw material, adequately pasteurized milk, ensuring the hygiene of food handlers' hands and implementing an efficient hygiene protocol.

The labels of these products did not show if they were categorized as being high humidity (46\%) or very high humidity $(55 \%)$ cheeses, which made it difficult to classify them under the standard categories proposed by the legislation. When the samples were analyzed at their expiration date, which ranged from 15 to 60 days after their date of production, most of them, except the self-called "light" and "lean" cheeses, showed changes in smell and appearance, such as an unpleasant smell, a noticeable change in texture and an overproduction of exudate. These changes are probably caused by the growth of psychrotrophic microorganisms. ROCHA et al. (2006) have confirmed that the deterioration is already visible 21 days after the production and, due to everything that has been said, the expiration dates must be reviewed. It is important to add that the packaging of artisanal cheeses did not have the expiration dates on them. However, during an informal conversation with the sellers, they recommended the daily washing of these dairy products up until its final consummation.

Only five samples of the same production lot showed a microbiological quality variation from acceptable to unacceptable when both analyses were compared (close to the date of production and at the expiration date). Apparently, the studied period did not influence the safety of consuming these cheeses.

As for the legislation, the use of microbiological parameters such as the number of coliforms at $45^{\circ} \mathrm{C}$ and positive-coagulase staphylococci count is questionable. It is known that some strains of Klebsiella, which might be of fecal or environmental origin, can ferment lactose when they are incubated at $45^{\circ} \mathrm{C}$ (CORRY et al., 2003). When we use the thermotolerant group as a hygiene and sanitary indicator, instead of using specifically $E$. coli, we run the risk of making a wrong assessment of these products' ability to carry pathogens. The same applies when we use plasma coagulation capacity to infer the presence of $S$. aureus because species such as the $S$. hyicus and $S$. intermedius can also synthesize the coagulase enzyme, but they do not interfere with food safety.

When revising the literature, we could observe that hygiene and sanitary conditions regarding this product are still precarious, just as we describe ahead. An outbreak that occurred in the city of Pará de Minas, Minas Gerais, Brazil, was associated with the consumption of Minas fresh cheese that was produced from raw milk. Salmonella was found in the studied samples (CERQUEIRA et al., 1994). PEREIRA et al. (1999) reported a count of coliforms at $45^{\circ} \mathrm{C}$ that exceeded the limit determined by law in $90 \%$ of the Minas fresh cheese samples studied in the city of Belo Horizonte, state of Minas Gerais, Brazil. In the city of Campina Grande, Paraíba, Brazil, CATÃO; CEBALLOS (2001) analyzed 75 samples of milk, of which 45 were raw milk, 15 were recently pasteurized milk

Table 2. Results of the microbiological analysis of Minas fresh cheeses commercialized in the city of Botucatu, São Paulo, Brazil, at the production and expiration dates, both of which are from the same lot.

\begin{tabular}{|c|c|c|c|c|c|}
\hline & \multirow{2}{*}{ Number of samples } & \multirow{2}{*}{$\mathrm{TtC} / \mathrm{g}\left(>5 \times 10^{2}\right)$} & \multirow{2}{*}{$\mathrm{CPS} / \mathrm{g}\left(>5 \times 10^{2}\right)$} & Salmonella & L. monocytogenes \\
\hline & & & & (Presence) & (Presence) \\
\hline 1 st Analysis & 50 & $18(36 \%)$ & $5(10 \%)$ & $1(2 \%)$ & 0 \\
\hline 2nd Analysis & 50 & $22(44 \%)$ & $7(14 \%)$ & 0 & $1(2 \%)$ \\
\hline Total & 100 & 40 & 12 & 1 & 1 \\
\hline
\end{tabular}

TtC: coliforms at $45^{\circ} \mathrm{C}$; CPS: coagulase-positive staphylococci. 
and 15 were bagged milk. They found L. monocytogenes in 26 $(57.78 \%)$ of those samples, of which $17(37.78 \%)$ were raw milk, and 9 (20\%) were processed milk (four recently pasteurized and five units of bagged milk). SALOTTI et al. (2006) investigated 60 samples of Minas fresh cheese in the city of Jaboticabal, São Paulo, Brazil, and found a coagulase-positive staphylococci count that exceeded the limit in nine samples, of which six were artisanal cheeses. We must remember that these articles show data from different states of Brazil and, therefore, different results.

Based on these results, we conclude that the hygiene and sanitary quality of Minas fresh cheeses are unsatisfactory, especially those of artisanal origin. We can also conclude that the time between their date of production and expiration date did not seem to interfere with its sanitary conditions (presence of pathogens). However, from a hygiene perspective, the period of validity of these products is too long, simply because the increase of deteriorating microorganisms, and, consequently, the changes in smell and appearance, would make it impossible for someone to consume these cheeses on the last of the expire date.

The presence of enterotoxigenic strains of $S$. aureus in three samples highlights the importance of correctly storage these products, because, if not stored properly, this can cause food poisoning in those who consume it. Generally speaking, poor hygiene quality and sanitary conditions of this products create risks to the health of the consumer, especially the children, the elderly, the pregnant women and the immunosuppressed individuals.

\section{ACKNOWLEDGMENT}

This work was supported by the Fundação de Amparo à Pesquisa do Estado de São Paulo (FAPESP) - Process no. 2015/08824-8.

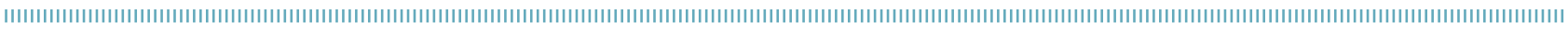
REFERENCES

ANDREWS, W.H.; FLOWERS, R.S.; SILLIKER, J.; BAILEY, J.S. Salmonella. In: DOWNES, F.P.; ITO, K. (Eds). Compendium of Methods for the Microbiological Examination of Foods. Washington, D.C.: APHA, 2001. p.357-380.

BRASIL. Resolução RDC no 12, de 2 de janeiro de 2001. 2001 . Available from: <http://portal.anvisa.gov.br/ documents/33880/2568070/RDC_12_2001.pdf/15ffddf63767-4527-bfac-740aO400829b >. Accessed on: Aug. 262017.

CATÃO, R.M.R.; CEBALLOS, B.S.O. Listeria spp., coliformes totais, fecais e $E$. coli no leite cru e pasteurizado de uma indústria de lacticínios no estado do Paraíba (Brasil). Ciência e Tecnologia de Alimentos, v.21, n.3, p.281-287, 2001.

CERQUEIRA, M.M.O.P.; SOUZA, M.R.; FONSECA, L.M.; RODRIGUES, R.; RUBINICH, J. Surto epidêmico de toxinfecção alimentar envolvendo queijo do tipo Minas Frescal em Pará de Minas. Arquivo Brasileiro de Medicina Veterinária e Zootecnia, v.46, n.6, p.723-728, 1994.

COMMUNITY REFERENCE LABORATORY FOR ANTIMICROBIAL RESISTANCE (CRLAR). Multiplex PCR for the Detection of the mecA Gene and the Identification of Staphylococcusaureus. Copenhagen: National Food Institute, Technical University of Denmark, 2009.

CORRY, J.E.L.; CURTIS, J.D.W.; BAIRD, R.M. Media for detection and enumeration of 'total' Enterobacteriaceae, coliforms and Escherichia coli from water and foods. In: CORRY, J.E.L.; CURTIS, J.D.W.; BAIRD, R.M. Handbook of Culture Media for Food Microbiology. United Kingdom: Elsevier, 2003. v.37. p.167-193.
DE BUYSER, M.L.; DUFOUR, B.; MAIRE, M.; LAFARGE, V. Implication of milk and milk products in food-borne diseases in France and in different industrialized countries. International Journal of Food Microbiology, v.67, p.1-17, 2001.

DONNELLY, C.B.; LESLIE, J.E.; BLACK, I.A.; LEWIS, K.H. Serological identification of enterotoxigenic staphylococci from cheese. Applied Microbiology, v. 15, p.1382-1387, 1967.

FEITOSA, T.; BORGES, M.F.; NASSU, R.T.; AZEVEDO, E.H.F.; MUNIZ, C.R. Pesquisa de Salmonella sp., Listeria sp. e microrganismos indicadores higiênico-sanitários em queijos produzidos no estado do Rio Grande do Norte. Ciência e Tecnologia de Alimentos, v.23, p. 162-165, 2003.

FURTADO, M.M. Problemas típicos do queijo minas frescal. In: Principais problemas dos queijos: causas e prevenção. São Paulo: Fonte de Comunicação e Editora, 1999. p. 155-160.

JOHNSON, W.M.; TYLER, S.D.; EWAN, F.E.; ASHTON, F.E.; POLLARD, D.R.; ROZEE, K.R. Detection of genes for enterotoxins, exfoliative toxins, and toxic shock syndrome toxin 1 in Staphylococcus aureus by the polymerase chain reaction. Journal of Clinical Microbiology, v.29, p.426-430, 1991.

KORNACKI, J.L.; JOHNSON, J.L. Enterobacteriaceae, coliforms and Escherichia coli as quality and safety indicators. In: DOWNES, F.P.; ITO, K. (Eds.). Compendium of Methods for the Microbiological Examination of Foods. Washington, D.C.: APHA, 2001. p.69-80.

KOUSTA, M.; MATARAGAS, M.; SKANDAMIS, P.; DROSINOS, E.H. Prevalence and sources of cheese contamination with pathogens at farm and processing levels. Food Control, v.2 1, p.805-815, 2010. 
LANCETTE, G.A.; BENNETT, R.W. Staphylococcus aureus and Staphylococcal Enterotoxins. In: DOWNES, F.P.; ITO, K. (Eds). Compendium of Methods for the Microbiological Examination of Foods. Washington, D.C.: APHA, 2001. p.387-403.

MARTIN, J.G.P.; SILVA, G.O.; FONSECA, C.R.; MORALES, C.B.; SILVA, C.S.P.; MIQUELLUTI, D.L.; PORTO, E. Efficiency of a cleaning protocol for the removal of enterotoxigenic Staphylococcus aureus strains in dairy plants. International Journal of Food Microbiology, v.238, p.295-301, 2016.

OLIVEIRA, C.A.F.; MORENO, J.F.G.; MESTIERI, L.; GERMANO, P.M.L. Características físico-químicas e microbiológicas de queijos Minas frescal e mussarela produzidos em algumas fábricas de laticínios do Estado de São Paulo. Higiene Alimentar, v.12, n.55, p.31-35, 1998.

OLIVEIRA, M.N.; BRITO, C. Brined cheeses and analogues of Latin American origin. In: TAMIME, A.Y. (Ed.). Brined cheeses. Oxford: Blackwell Publishing, 2006. p.211-248.

PEREIRA, M.L.; GASTELOIS, M.C.A.; BASTOS, E.M.A.F.; CAIAFFA, W.T.; FALEIRO, E.S.C. Enumeração de coliformes fecais e presença de Salmonella sp. em queijo-de-minas. Arquivo Brasileiro de Medicina Veterinária e Zootecnia, v.51, p.427-431, 1999.

PEREIRA, M.L.; LARA, M.A.; DIAS, R.S.; CARMO, L.S. Intoxicação por Staphylococcus aureus provocada por queijo "tipo Minas". Microbiologia, São Paulo, v.22, p.349-350, 1991.

RALL, V.L.M.; VIEIRA, F.P.; RALL, R.; VIEITIS, R.L.; FERNANDES JR., A.; CANDEIAS, J.M.G.; CARDOSO, K.F.G.; ARAÚJO JR., J.P. PCR detection of staphylococcal enterotoxin genes in Staphylococcus aureus strains isolated from raw and pasteurized milk. Veterinary Microbiology, v.132, p.408-413, 2008.

ROBBINS, R.; GOULD, S.; BERGDOLL, M.S. Detecting the enterogenicity of Staphylococcus aureus strains. Applied Microbiology, v.28, p.946-950, 1974.

ROCHA, J.S.; BURITI, F.C.A.; SAAD, S.M.I. Condições de processamento e comercialização de queijo-de-minas frescal. Arquivo Brasileiro de Medicina Veterinária e Zootecnia, v.58, n.2, p.263-272, 2006.

RYSER, E.T.; DONNELLY, C.W. Listeria. In: DOWNES, F.P.; ITO, K. (Eds). Compendium of Methods for the Microbiological Examination of Foods. 4. ed. Washington, D.C.: American Public Health Association, 2001. p.343-356.

SALOTTI, B.M.; CARVALHO, A.C.F.B.; AMARAL, L.A.; VIDALMARTINS, A.M.C.; CORTEZ, A.L. Qualidade microbiológica do queijo minas frescal comercializado no município de Jaboticabal, SP, Brasil. Arquivos do Instituto Biológico, v.73, n.2, p.171-175, 2006.

SENA, M.J.; CERQUEIRA, M.M.O.P.; MORAIS, C.F.A.; CORRÊA, E.S.; SOUZA, M.R. Características físico-químicas de queijo de coalho comercializado em Recife-PE. Higiene Alimentar, v.14, n.74, p.41-44, 2000.

SILVA, M.M.I.; ALMEIDA, R.C.C.; ALVES, M.A.O.; ALMEIDA, P.F. Occurrence of Listeria spp. in critical control points and the environment of Minas Frescal cheese processing. International Journal of Food Microbiology, v.81, p.241-248, 2003. 